\title{
ACTIVITIES IN TEACHING ENGLISH VOCABULARY FOR YOUNG LEARNERS IN FIVE KINDERGARTENS IN INDRAMAYU
}

\author{
Natalia Anggrarini \\ English Education Department \\ Wiralodra University - Indramayu (West Java) \\ Email:natalia.anggrarini@unwir.ac.id
}

\begin{abstract}
Childhood Education essentially aims at providing stimulation in all aspects of child development especially in language development. This study is attempted to investigate activities in teaching English vocabulary to young learners. To provide good education in early childhood the teacher has to understand their characteristics and know their needs according to their developmental level. In accordance with the world of early childhood, children learn through play (learning through play) and interesting learning process for them (playing is learning).Thus, the teacher needs to provide activities that meet the students needs and present them in a proper way. This study describes the activities done by teachers in five kindergartens in Indramayu. The participants in this study were five teachers in those five kindergartens. The findings showed that the teachers in five kindergartens in Indramayu taught vocabulary by presenting some activities such as; listen and do, listen and repeat, modeling and demonstration, singing song, look and say, listen and identify, and question and answer. In Grade A the dominant activity was Listen and Repeat with frequency $40 \%$ in one semester while in Grade B, Look and say was the dominant activity with frequency 30,76\% in one semester. Those activities are done based on the consideration that the activities done in Grade A were emphasized on their level of development such as imitating. While children in Grade B were more developed, the activities were emphasized on recognizing word and learn to pronounce it clearly.
\end{abstract}

Keywords: Leaning Activity, Teaching Vocabulary, Teaching English for Young Learners

\begin{abstract}
Abstrak
Pendidikan anak-anak utamanya bertujuan untuk memberikan stimulus di segala aspek perkembangan anak khususnya perkembangan bahasa. Penelitian ini dilakukan sebagai upaya untuk menginvestigasi kegiatan dalam mengajar kosakata bahasa inggris untuk anak-anak. Dalam memberikan pendidikan yang baik bagi anak usia dini, guru harus memahami karakteristik dan kebutuhan anakanak sesuai dengan tahapan perkembangan mereka. Sejalan dengan dunia anakanak, mereka belajar melaui kegiatan bermain (belajar sambil bermain) dan proses belajar yang menyenangkan untuk mereka (bermain adalah belajar). Untuk itu, guru harus mempersiapkan kegiatan yang sesuai dengan kebutuhan siswa dan
\end{abstract}


melakukannya dengan cara yang tepat. Penelitian ini menggambarkan kegiatan yang dilakukan oleh guru di lima taman kanak-kanak (TK) di Indramayu. Peserta dalam penelitian ini adalah lima guru yang berasal dari lima taman kanak-kanak (TK) di indramayu. Temuan dari penelitian ini menunjukan bahwa guru-guru di lima TK tersebut mengajarkan kosa kata bahasa inggris melalui kegiatan seperti: listen and do (Dengar dan Lakukan), listen and repeat (Dengar dan Ulang), modeling and demonstration (Mencontohkan dan Menunjukkan), singing song (Bernyanyi), look and say (Lihat dan Ucapkan), listen and identify (Dengar dan Kenali), and question and answer (Tanya jawab). Kegiatan yang dominan dilakukan di TK Tingkat A adalah Listen and Repeat (Dengar dan Ulang) dengan frekuensi $40 \%$ dalam satu semester. Sedangkan pada TK tingkat B kegiatan yang paling dominant dilakukan adalah Look and Say (Lihat dan Ucapkan) dengan frekuensi $30.67 \%$ dalam satu semester. Hal tersebut dilakukan dengan pertimbangan bahwa kegiatan tersebut sesuai dengan tingkat perkembangan bahasa pada usia mereka, dimana anak-anak di TK tingkat A masih ditekankan pada kegiatan meniru. Sedangkan anak-anak TK pada tingkat B sudah lebih berkembang dimana kegiatannya lebih ditekankan pada mengenali kata dan belajar untuk membunyikan (mengucapkan) kata tersebut.

Kata Kunci: Aktifitas Belajar, Pengajaran Kosakata, Pengajaran Bahasa Inggris bagi Pemula

\section{INTRODUCTION}

English is a very important language because it is used in almost all areas of life, such as college, government, business, tourism, entertainment, and others. Due to its importance, English language becomes the first foreign language that is taught in earlier stage since the early 90's. The development of our world, demands Indonesians to be able to communicate in English, thus students need to master vocabulary. According to Hedge (2000), in learning a foreign language, vocabulary plays an important role. It is one of the most important aspects of the foreign language learning. Rich vocabulary helps people to understand and learn new languages.

Vocabulary is an important and essential element in language learning. Vocabulary as one of the main components should be taught since the beginning level (young learners) (Pinter, 2006). This is important because the mastery of vocabulary affects the mastery of the four language skills (listening, 
speaking, reading, and writing) (Pikulski \& Temleton, 2004). Teaching vocabulary to children is different from teaching vocabulary to teenagers and adults, because different age has different needs, competencies, and cognitive skill (Harmer, 2001).

In relation to the teaching of vocabulary for young learners, it is interesting to know the activities conducted in teaching vocabulary to young learners in kindergartens in Indramayu. On the preliminary observation, the students seemed to be interested in learning about English and when they knew it they were happy to learn it and they felt that learning English was fun. When the teacher asked the students about what they had learnt in the previous meeting, most of them still remembered it well. There would be one observation to each of the grade level. The observation was conducted one time for each class to find out the similar techniques used by the English teachers in five kindergartens in Indramayu in teaching English vocabulary in grade
A grade B. By the end of the research, the information of conducting the appropriate activities in teaching vocabulary for different grades were collected.

\section{Teaching English to Young Learners}

Teaching English to young learner especially to foreign language learners is not an easy way. Teacher should find interesting and creative way to teach English to foreign language learners. Vocabulary becomes one element of language that firstly taught. Scoot and Yetreberg (1990) define the characteristic of young language learners:

1. They can talk about what they are doing

2. They can tell you about what they have done or heard

3. They can plan activities

4. They can argued for something and tell why they think what they think

5. They can use logical reasoning

6. They can use their vivid imaginations 
7. They can use a wide range of intonation patterns in their mother tongue

8. They can understand direct human interaction

Young language learners use language skills although they are not aware about it. They are often happy playing and working alone but in the company of other. They also love to play and learn best when they enjoy the activity. They are also enthusiastic and positive about learning since their curiosity is high in their age. Those means teaching language should be done by considering their characteristics and language development. In teaching language to young learners, Scott and Ytreberg also explain several point to consider for the teacher (1) words are not enough, (2) play with language, (3) language as language (4) variety in classroom, (4) Routines, (5) cooperation not competition, (6) grammar, (7) assessment.

Learning activities that can be done in kindergarten classroom are classified based on the focus of learning.

In listening, the activities are:

1. Listen and do

2. Listening for information

3. Listen and repeat

4. Listening to stories

5. Independent listening

In speaking, the activities are:

1. Presenting new language orally

2. Controlled practice

3. Guided practice

4. Dialogue and role play

5. Free activities

In reading, the activities are:

1. Reading a story from a book

2. Reading a class story

3. Reading text based on the child's language

4. Reading aloud

5. Silent reading

In writing, the activities are:

1. Controlled writing activities

2. Guided writing activities

3. Free writing activities 
METHOD

This study employs a descriptive-qualitative design. Qualitative research is more flexible and has natural setting as the direct source of data is the key instrument (Bogdan and Biklen (1984), Lodico, Spaulding \& Voegtle, 2006 p.265) According to In this study, the instruments used were observation and interview. The teachers were observed and interviewed and the documentation was done by the researcher. The population of this study was five kindergartens in Indramayu with five Teachers as participants in this research. The result of this study is in the form of description which focused more on the process than the product of the study.

The data was taken by observing the teaching and learning process, interviewing the English teacher, and doing documentation. The observation was conducted in the attempt to identify and describe the techniques used by the kindergarten teachers in teaching vocabulary in grade A and B. For the observation, three instruments were used, they were; observation checklist, field note and Smartphone recorder/camera digital. The interview was conducted to know the background of the teachers' education, teaching techniques and the students respond as well as evaluation.

After all the data were collected, they were organized and categorized. The field notes that were written during the observation . The data was organized by categorizing the field notes using number 1 for class $\mathrm{A}$ and $\mathrm{B}$. Observation was done 1 times in 1 class. After that, the result of checklist, interview, and field notes were separated. All checklists were synthesized along with other results. The last step to analyze the qualitative data was summarizing. To summarize it, the researcher selected the related data, described and presented descriptively. 


\section{FINDINGS AND DISCUSSION}

\section{Findings}

Based on the instruments used to collect the data in kinds of techniques, the here are the findings. The researcher found the data based on the observation checklist and field notes. These findings were collected from two grades, grade A and grade B. The findings on kind of techniques can be seen in Table 1 and 2.

Table 1. Techniques in teaching vocabulary in Grade A

\begin{tabular}{|l|l|l|}
\hline \multicolumn{1}{|c|}{ Duration } & \multicolumn{1}{c|}{ Topic } & \multicolumn{1}{c|}{ Technique } \\
\hline 30 minutes & Part of body & Sing a song \\
\hline 30 minutes & Part of body & Listen and repeat \\
\hline 30 minutes & Numbers & Sing a song \\
\hline 30 minutes & Numbers & Listen and repeat \\
\hline 30 minutes & Colors & Sing a song \\
\hline 30 minutes & Colors & Listen and repeat \\
\hline 30 minutes & Part of body & $\begin{array}{l}\text { Listen and identify } \\
\text { (Reinforcement) }\end{array}$ \\
\hline 30 minutes & Numbers & \begin{tabular}{l} 
Listen and identify \\
(Reinforcement) \\
\cline { 2 - 3 }
\end{tabular} \\
\hline 30 minutes & $\begin{array}{l}\text { Listen and repeat } \\
\text { (Reinforcement) }\end{array}$ \\
\hline
\end{tabular}

Table 2. Techniques in teaching vocabulary in Grade B

\begin{tabular}{|l|l|l|}
\hline \multicolumn{1}{|c|}{ Duration } & \multicolumn{1}{c|}{ Topic } & Technique \\
\hline 30 minutes & Fruits & Listen and Repeat \\
\hline 30 minutes & Fruits & Look and say \\
\hline 30 minutes & Part of body & Listen and do \\
\hline 30 minutes & Part of body & Listen and repeat \\
\hline 30 minutes & Part of Body & Look and say \\
\hline 30 minutes & Numbers & Sing a song \\
\hline 30 minutes & Numbers & Look and say \\
\hline 30 minutes & Colors and shapes & Sing a song \\
\hline 30 minutes & Colors and shapes & Look and say \\
\hline 30 minutes & Part of body & $\begin{array}{l}\text { Modeling and } \\
\text { demonstration }\end{array}$ \\
\hline 30 minutes & Part of body & Listen and identify \\
\hline
\end{tabular}




\begin{tabular}{|l|l|l|}
\hline 30 minutes & Colors and shapes & Question and answer \\
\hline 30 minutes & Part of body & Question and answer \\
\hline
\end{tabular}

Those are the topic as well as the duration of learning activity for one semester. Each meeting was given in a day. English subject is given once a week. The schedule of English is on Saturday (grade A and B).

To conclude here is the table to sum up the activities.

Table 3. Results of Techniques in Teaching Vocabulary

\begin{tabular}{|l|c|c|c|c|c|c|}
\hline \multicolumn{1}{|c|}{ Activities } & Grade A & $\mathrm{f}$ & $\%$ & Grade B & $\mathrm{f}$ & $\%$ \\
\hline Sing a song & $\sqrt{ }$ & 3 & $30 \%$ & $\sqrt{ }$ & 2 & $15.38 \%$ \\
\hline Listen and Repeat & $\sqrt{ }$ & 4 & $40 \%$ & $\sqrt{ }$ & 2 & $15.38 \%$ \\
\hline Listen and Identify & $\sqrt{ }$ & 3 & $30 \%$ & $\sqrt{ }$ & 1 & $7.69 \%$ \\
\hline Listen and do & & & & $\sqrt{ }$ & 1 & $7.69 \%$ \\
\hline Look and say and & & & & $\sqrt{ }$ & 4 & $30.76 \%$ \\
\hline $\begin{array}{l}\text { Modeling and } \\
\text { demonstration }\end{array}$ & & & $\sqrt{ }$ & 2 & $15.38 \%$ \\
\hline $\begin{array}{l}\text { Question } \\
\text { answer }\end{array}$ & & & & & \\
\hline
\end{tabular}

Kinds of Techniques Used in Teaching Vocabulary to the Grade $A$ and $B$

\section{Grade A}

In terms of materials, there were three main topics given to students in grade A. they were parts of body (10 vocabularies), numbers vocabularies from one to ten), and colors (10 vocabularies).

In terms of activities, the teachers in five kindergartens in Indramayu taught English to the learner by doing three activities they were sing a song, listen and repeat, and listen and identify. Here are the elaboration.

Sing a Songs activities were done by the teacher to make the students enjoy the English lesson. The activities mostly are done by the teachers in Grade A with $30 \%$ done from whole activities in English teaching and learning in one semester. The consideration of this is based on the characteristic of the students. This is also accordance with the result of interview in which the teachers' reason was to make the 
students enjoy the learning and make them familiar with the vocabularies. The teachers got the song from youtube with consideration to give more interesting songs to them. Some other teachers modified Indonesian kids song into English with consideration to make the students familiar with the rhythm of the songs so they can remember easily.

Listen and Repeat activity was done by the teachers to introduce new vocabulary. This technique was dominantly used by the English teachers at kindergarten with $40 \%$ done in a whole activity in one semester. The teachers used listen and repeat technique in teaching grade $\mathrm{A}$ to provide the pronunciation of the words. Since English is not their language, they might feel confused in spelling the words. In this activity, the teachers gave the pronunciation then asked the students to repeat after the words.

Listen and Identify activity was done by the teachers in kindergarten as reinforcement. This activity was done with $30 \%$ for one semester in grade A. Usually this activity was done after the students got listen and repeat activity. This was done to check their memory. The teacher pronounced the words and the students identified the object, the object was in form of picture.

\section{Grade B}

In grade $\mathrm{B}$, the students have shown their development in learning, as well as in English learning. The teachers provided more topics as well as variety activities in this grade. There were five main topics given in this grade such as fruits, part of body, numbers, colors and shapes. The activities given were sing $a$ song, listen and repeat, listen and identify, listen and do, look and say, modeling and demonstrating, and question and answer.

Sing a song activity in Grade B was done with $15,38 \%$ from whole activities in one semester. The consideration is based on the complexity of activities should be done in this grade because the children have higher level of language development so the activities should be done in variety. 
The students have been familiar with English songs, because they have been learning the song from grade A the teacher built

Listen and Repeat activity in Grade B was done with $15,38 \%$ in the classroom for one semester. The teachers consider this activity was needed to familiarize them with pronunciation of English vocabulary.

Listen and Identify activity was done by the teachers in kindergartens as reinforcement. This activity was done with $7.69 \%$ for one semester in grade B. The frequency of this activity decreased in grade B. The teacher considered that this activity was only needed as reinforcement. So it was done in shorter time.

Listen and Do technique was also used by the teachers when they made introduction to the lesson or asked the students to do something. In this activity the teacher gave instruction and the students did what the teacher said. The teacher used this technique with frequency $7.69 \%$. In teaching grade $B$, the teacher always asked the students to sit down and listen to the teacher before she made introduction to the lesson.

Look and Say activity was introduced in Grade B with consideration; this grade was expected to recognize English words. The frequency of this activity was $30.76 \%$. It was the highest frequency among others activities. Mostly the teacher prepares one word in one paper and asks them to say the word.

Modeling and Demonstrating activity was done in Grade B with frequency $7.69 \%$. Usually it was given in form of active verbs. The students were given a model of action and they demonstrate it after the teachers say the words. This is similar to listen and do; the difference is on modeling action.

Question and Answer activity was done with frequency $15.38 \%$ in grade B. The students were introduced with English question and answer. The teachers gave question such as "what is this" and also provide them with answer "this is apple". The teachers repeated question and the way to answer the question until the students felt 
familiar with the question and answer.

\section{Discussion}

Sing a songs technique was used by the teacher to make the students enjoy the English lesson. Using songs was good idea to make them enjoy because children have short attention. Scott \& Ytreberg (1990 in Rohqim, 2005), state that several characteristics of young learners affect the language learning. First, children's attention or concentration is considerably shorter that adult. To have children's attention, teacher need to provide enjoyable activities, one of enjoyable activities for children is singing together. Singing song could enrich their vocabulary. Based on the observation, Singing Songs is oftenly used by the teacher to teach vocabulary.

Listen and Do technique was used by the teacher when she made introduction to the lesson or asked the students to do something. In this activity the teacher gave instruction and the students did what the teacher said. The teacher used this technique many times. According to Suyanto (2007) this activity was used to know students' comprehension of the instruction and the students showed their comprehension by doing the instruction. During the observation, the use of this technique was not varied. The teacher always used the same instruction, such as; sit down please, silent, open your book.

Scott and Ytreberg (1990 in Rohqim, 2005) suggest some techniques/activities to teach young learner in listen and do activity.

1. Giving an instruction

Giving an instruction is very important since communication is two-way, and everything will be able to run well if the students understand the instruction / message.

2. Moving about

The younger the children, the more physical activities they need. This activity should be connected with doing ordinary things in the classroom.

3. Put up your hands

Teacher can use these activities in any situation. For example, 
when the children are listening to a teacher's story, the teacher asks them to put up their hand when they hear certain words.

4. Miming story

It might be used when the teacher teaches facial expression like happy, sad, crying, etc. The teacher can tell a very simple story and ask the students to express what is happening in the story. It will help the students to understand words without really know the exact meaning.

\section{Drawing}

Listen and draw might be a favorite activity in the classroom since children like drawing very much. This activity is particularly useful for checking objects vocabulary, preposition, colors, and numbers.

Listen and Repeat technique was used by the teacher to introduce new vocabulary or read a text. It was done continually and it made the students familiar with that. Cameron (2001 p.8) states that in the development of children's vocabulary for teaching, the students need to meet word again and again in new context that help increase what they know about words. The findings showed that the teacher and students' voice were the most essential part. But the teacher made some pronunciations problem. As the model, the teacher should be careful in pronouncing the words. For example, when the teacher pronounced a word "Identify" it sounds "identifíi". According to Suyanto (2007) teachers should be the good model for the young learners. It means that the teacher should have capability in speaking English, especially in pronunciation. The children hear and imitate what the teacher says. In this case, the use of dictionary is recommended to minimize the risk of pronunciation problem.

Brainstorming was applied by the teacher to activate the students. In this technique the teacher asks the students to give their ideas or mention examples as many as possible. But, during the observation, the teacher directly corrected the students' mistakes if they mentioned examples that were not suitable to 
the theme. According to Suyanto (2007), she states that if the teacher asks the students to give their ideas or mention examples as much as possible in a certain time, so the teacher has to do brainstorming. In this case the students are usually braver to show their ideas because the teacher would not say true or false. All of the ideas would be written on the board and then the teacher leads the students to find the appropriate idea for the answer.

Modeling and Demonstration technique was only used by the teacher when she taught how to say something. For example, the teacher gave example how to pronounce words and the students followed her. During the observation, the teacher's voice was clear and the students can hear her voice clearly. But some pronunciation problems were made by the teacher. For example, when the teacher pronounced a word "Identify" it sounds "identifíi". The teacher also missed " $\mathrm{S}$ " in pronounce "teachers' office" and the teacher also gave less attention to " $\mathrm{S}$ " as plural in writing or pronouncing "students become student". According to Allen (1965 p.312 in Rohqim, 2005) "a more important meaning of modeling, however, is that the teacher's language is the model itself. Children are great imitators. They don't need to be asked to imitate all the time in order to learn. They "catch" how the teacher speaks the language and not what she tells them to repeat after her". Techniques Used in Teaching Grade B.

\section{CONCLUSION}

Concerning the result of the findings and discussion of the study, it could be concluded that the teachers in five kindergartens in Indramayu taught vocabulary by presenting some activities such as; listen and do, listen and repeat, modeling and demonstration, singing song, look and say, listen and identify, and question and answer. In Grade A the dominant activity was Listen and Repeat with $40 \%$ frequency in one semester while in Grade B, Look and say was the 
dominant activity with $30,76 \%$ frequency in one semester.

\section{REFERENCES}

The activities in teaching vocabulary in five kindergartens were various, it made the students enjoy the English lesson. The teachers tried to make their students understand the English material in teaching and learning process. The selection activities were adjusted to the level, time and theme. The teacher used simple vocabulary and sentence that was appropriate to the theme.

From the result of this study, the teachers was suggested to improve the activities or give more various activities in the teaching and learning process in the classroom. Advance knowledge in teaching English to Young learners is needed for the improvement of English learning activity in kindergarten. Cameron, Lynn. (2001). Teaching Languages to Young Learners. New York: Cambridge University Press

Harmer, J. 2007. (1985). How to Teach English. Essex: Pearson Longman.

Hedge, T. (2000). Teaching and Learning in the Language Classroom. Oxford: Oxford University Press.

Anggrarini, Natalia. (2017). English for Children-Compilation of materials. Wiralodra University Press. Indramayu

Pinter, A. (2006). Teaching young language learners. China: Oxford University Press.

Suyanto, K. E. (2007). English for Young Learners. Jakarta: PT. Bumi Aksara.

Wendy, A Scott and Lisbeth $\mathrm{H}$. Ytreberg. (1990). Teaching English to Children Longman

Wortham, Sue C. (2006). Early Childhood Curriculum . Pearson

Further research is expected to find out kindergarten teachers' proficiency in teaching English. 